\begin{tabular}{|l|c|c|c|c|}
\hline $\begin{array}{l}\text { Cuadernos de Investigación Geográfica } \\
\text { Geographical Research Letters }\end{array}$ & 2020 & N $^{\circ} 46(1)$ & pp. 7-31 & eISSN 1697-9540 \\
\hline
\end{tabular}

DOI: http://doi.org/10.18172/cig.3800

(C) Universidad de La Rioja

\title{
EFFECT OF HYALOCLASTITE BRECCIA BOULDERS ON MESO-SCALE PERIGLACIAL-AEOLIAN LANDSYSTEM IN SEMI-ARID ANTARCTIC ENVIRONMENT, JAMES ROSS ISLAND, ANTARCTIC PENINSULA ${ }^{1}$
}

\author{
M. KŇAŽKOVÁ* , F. HRBÁČEK, J. KAVAN, D. NÝVLT \\ Department of Geography, Masaryk University, Brno, Czech Republic
}

\begin{abstract}
In this study we aim to describe the processes leading to the creation of a specific periglacial and aeolian landsystem, which evolves around the hyaloclastite breccia boulders on James Ross Island, north-eastern Antarctic Peninsula. These boulders were deposited as a result of the Late Holocene advance of Whisky Glacier, forming a well-developed boulder train approximately 5-km long, stretching from Whisky Glacier moraine to Brandy Bay. The combination of ground temperature monitoring, snow cover measurements, grain size analysis and field survey were used to quantify and understand the interplay of periglacial and aeolian processes leading to the formation of the specific meso-scale landsystem around the boulders. The ground temperature probes were installed during January 2017 in the vicinity of two selected boulders. The two study sites, at Monolith Lake (large boulder) and Keller Stream (smaller boulder), were also fitted with snow stakes and trail cameras. An automatic weather station (AWS) on the Abernethy Flats, located approximately two kilometres to the north-west, was used as a reference site for ground temperature and snow cover thickness. The hyaloclastite breccia boulders act as obstacles to wind and trap wind-blown snow, resulting in the formation of snow accumulations on their windward and lee sides. These accumulations affect ground thermal regime and lead to the transport of fine particles by meltwater from the snow during the summer season. The snow cover also traps wind-blown fine sand resulting in the formation of finegrained rims on the windward and lee sides of the boulders after the snow has melted. Furthermore, the meltwater affects ground moisture content, creating favourable, but spatially limited conditions for colonisation by mosses and lichens.
\end{abstract}

1 This paper has received the First Prize and Honorable Mention (shared) from the Young Researcher Innovation Award on Cryosphere Science, granted by the Research Group on Physical Geography in High Mountains, Complutense University of Madrid (Department of Geography), Spain. 
Importancia de los bloques de hialoclastita en la morfogénesis periglaciar y eólica a escala media en ambiente semiárido antártico, Isla James Ross, Península Antártica

RESUMEN. En este trabajo tratamos de describir los procesos que conducen a la creación de un sistema específico periglaciar y eólico, que evoluciona alrededor de bloques de hialoclastita en la Isla James Ross, nordeste de la Península Antártica. Estos bloques fueron depositados como resultado del avance a finales del Holoceno del Glaciar Whisky, formando un cordón de bloques de unos $5 \mathrm{~km}$ de longitud, desde la morrena del Glaciar Whisky hasta la Bahía Brandy. La combinación del seguimiento de la temperatura del suelo, medidas de la cubierta nival, análisis granulométricos y trabajo de campo permitieron cuantificar y entender las interacciones de los procesos periglaciares y eólicos que conducen a la formación de un sistema específico a mediana escala alrededor de los bloques. Se instalaron sondas de temperatura del suelo en enero de 2017 en la proximidad de dos bloques seleccionados. Los dos lugares de estudio, en el Lago Monolith (bloque mayor) y el río Keller (bloque menor), fueron también controlados con estacas de nieve y cámaras de seguimiento. Una estación meteorológica automática en los Abernethy Flats, localizada aproximadamente $3 \mathrm{~km}$ al nordeste, fue utilizada como lugar de referencia para la temperatura del suelo y el espesor de la cubierta nival. Los bloques brechosos de hialoclastita actúan como obstáculos y atrapan la nieve desplazada por el viento, dando lugar a la formación de acumulaciones de nieve a sotavento y barlovento. Estas acumulaciones afectan al régimen termal del suelo y conducen al transporte de partículas finas por el agua de fusión durante el verano. La cubierta nival también atrapa arena fina transportada por el viento, dando lugar a la formación de anillos de arena fina en los lados de sotavento y barlovento de los bloques, una vez que la nieve ha fundido. Además, el agua de fusión afecta al contenido de humedad del suelo, creando condiciones favorables, aunque espacialmente limitadas, para la colonización por musgos y líquenes.

Key words: Ground sorting, periglacial environment, Antarctica, wind accumulation, snowmelt.

Palabras clave: ordenación de suelos, ambiente periglaciar, Antártida, acumulación eólica, fusion nival.

Received: 30 October 2018

Accepted: 25 January 2019

*Corresponding author: Michaela Kňažková, Department of Geography, Masaryk University, Brno, Czech Republic. E-mail address: michaelaknazkova@gmail.com 


\section{Introduction}

Ice-free areas in Antarctica, in which periglacial processes dominate, form less than $0.5 \%$ of the continent (Burton-Johnson et al., 2016; Hrbáček et al., 2019). Moreover, significant parts of the ice-free areas are formed by rock outcrops or nunataks, which prevent the development of soils. Nevertheless, sorted ground can be found covering the whole range of deglaciated surfaces in Antarctica, regardless of age. The oldest sorted ground can be found in Victoria Land, and are estimated to be in excess of 8.1 Ma (Marchant et al., 2002). In the Antarctic Peninsula region, the origin of sorted ground is related to the Late Pleistocene-Holocene deglaciation of the area (Ó Cofaigh et al., 2014); however, sorted ground in the early stage of development have also been observed in areas that have become deglaciated during the last few decades (e.g. Oliva and Ruiz-Fernandéz, 2015). Mapping of periglacial landforms in the South Shetland Islands suggests that sorted ground form about $20 \%$ of all ice-free surfaces in this region (Lopéz-Martínez et al., 2012).

Wind is an important geomorphic agent in both hot and cold desert environments (e.g. Koster and Dijkmans, 1988; McKenna Neuman, 1993; Seppälä, 2004), mainly resulting from the absence of ground-protective vegetation. Analogies can therefore be drawn between some of the features commonly observed in the hot deserts of the world and the ice-free areas of Antarctica (McKenna Neuman, 2004). Wind derived landforms are especially common in the Antarctic regions with an abundance of source material and sufficient wind velocities. Ripples reaching a height of several decimetres have been reported from Marion Island (Hedding et al., 2015), as well as dunes located near Canada Glacier in Taylor Valleys (Šabacká et al., 2012). The largest Antarctic dune field, Packard Sand Dunes, covers an area of approximately $1.5 \mathrm{~km}^{2}$ near Lake Victoria in the McMurdo Dry Valleys (McGowan et al., 2014).

One of the most important group of processes acting in periglacial environments are aeolian and niveo-aeolian processes (French, 2017). In the polar regions, comparatively little research has been conducted on this topic until present (Hedding et al., 2015). Traditionally, the majority of the studies dealing with these processes and their dynamics in cold regions were focused on sedimentation rates (e.g. Koster and Dijkmans, 1988; McKenna Neuman, 1993; Brookfield, 2011), a situation which was similar for research conducted on niveo-aeolian processes in Antarctica (e.g. Lancaster, 2004; Ayling and McGowan, 2006; Atkins and Dunbar, 2009; Gillies et al., 2013). Consequently, studies in to landform evolution (e.g. Speirs et al., 2008; Bourke et al., 2009), as well as the role that niveo-aeolian erosion plays in rock weathering (e.g. Matsuoka et al., 1996; Hedding et al., 2015) are limited to a few pioneering investigations.

In this paper, we present the findings of a study investigating the interplay between periglacial and aeolian processes forming a specific landsystem around hyaloclastite breccia boulders on James Ross Island, Eastern Antarctic Peninsula. Landsystem approach includes the range of processes and forms; and their relationships associated with the past and present geographic setting of the area (Eyles, 1983; Benn and Evans, 2010). Mostly glacial, periglacial, or paraglacial landsystems and associated sedimentlandform assemblages were defined in the literature (Evans, 2003; Davies et al., 2013; Kovanan and Slaymaker, 2015). The assemblages can be recognised at a range 
of scales, from the site to the continent scale. The hierarchical approach is a powerful means of describing how sediments and landforms fit together, and determining how organisation in the landscape reflects the depositional processes and external controls in the environment. In our case, we intent to describe the processes and forms at the site and its surroundings, which is referred to as the meso-scale level. However, it is probably the first time when such a periglacial-aeolian landsystem at the meso-scale was described from Antarctica. The main objectives of this study are: (i) to describe the processes leading to the formation of snow accumulation and its geometry around the boulders, (ii) to quantify the effect of snow on ground thermal regime, and 3) to discuss the role of hyaloclastite breccia boulders on the formation of specific meso-scale landforms in the periglacial environment of semi-arid maritime Antarctica.

\section{Study area}

James Ross Island lies off the northeastern coast of the Antarctic Peninsula (Fig. 1). It covers an area of approximately $2500 \mathrm{~km}^{2}$ in the altitudinal range of $0-1630 \mathrm{~m}$, of which approximately $25 \%$ is ice-free. The largest ice-free area on James Ross Island is the Ulu Peninsula, which covers approximately $300 \mathrm{~km}^{2}$, and is also the largest ice-free area within the Antarctic Peninsula region.

The climate of James Ross Island is classified as semi-arid polar as it lies in the precipitation shadow of the Antarctic Peninsula mountain range. Estimates of average annual precipitation range between $200-500 \mathrm{~mm}$, most of which falls in the form of snow (van Lipzig et al., 2004). However, snow accumulation distribution across James Ross Island is spatially heterogeneous as a result of strong winds.

The geological composition of James Ross Island comprises Jurassic to Cretaceous sedimentary rocks of the James Ross Basin (del Valle et al., 1992), which crop out mostly in the low-lying areas of James Ross Island (Mlčoch et al., 2018). The Mesozoic strata are protruded and overlain by Neogene to Quaternary rocks of the James Ross Island Volcanic Group (Nelson, 1975; Smellie et al., 2013), which consists of various types of hyaloclastites, basaltic lavas, dykes and subordinate pyroclastic rocks (Košler et al., 2009; Altunkaynak et al., 2018) that predominantly originate in a subglacial setting (Smellie et al., 2008). At the Abernethy Flats, siltstones and sandstones of the Alpha Member of the Santa Marta Formation (Olivero et al., 1986; Crame et al., 1991) are covered by boulders of hyaloclastite breccia brought to the area from the Stickle Ridge and Smellie Peak volcanic elevations during the Holocene advance of Whisky Glacier, forming well-developed boulder trains (Hjort et al., 1997; Davies et al., 2013).

The deglaciation of Ulu Peninsula is altitude-dependent, with the low-lying areas (< $50 \mathrm{~m}$ a.s.1.) having become deglaciated during the late Pleistocene (12.9 \pm $1.2 \mathrm{ka}$; Nývlt et al., 2014); however, areas of mid-altitudes (200-400 m a.s.1.) remained ice-covered throughout the early Holocene (Johnson et al., 2011). During the midHolocene, glacier extent was broadly similar to present glacial coverage (Glasser et al., 2014). The mid-late Holocene is characterised by Neoglacial advances of local glaciers that have been recognised from Ulu Peninsula based on sedimentary sequences 
of glacial landforms (Hjort et al., 1997) and associated lacustrine records (Björck et al., 1996). Modelling experiments suggest that glaciers on Ulu Peninsula remained stable during the mid-late Holocene, and that the Neoglacial re-advance took place in the last millennium, or during the local Little Ice Age (Davies et al., 2014). Current glacier systems include ice aprons, cirque, piedmont and land-terminating valley glacier, as well as small ice caps located on volcanic mesas (Carrivick et al., 2012; Engel et al., 2012). To the south, the ice-free area of Ulu Peninsula is bounded by the Dobson Dome and Mt. Haddington Ice Caps (Davies et al., 2012). All of these glaciers have experienced a pronounced amount of mass loss during the previous few decades (Davies et al., 2012; Engel et al., 2012; Seehaus et al., 2018); however, positive mass balances have been observed between 2009 and 2015 (Engel et al., 2018).

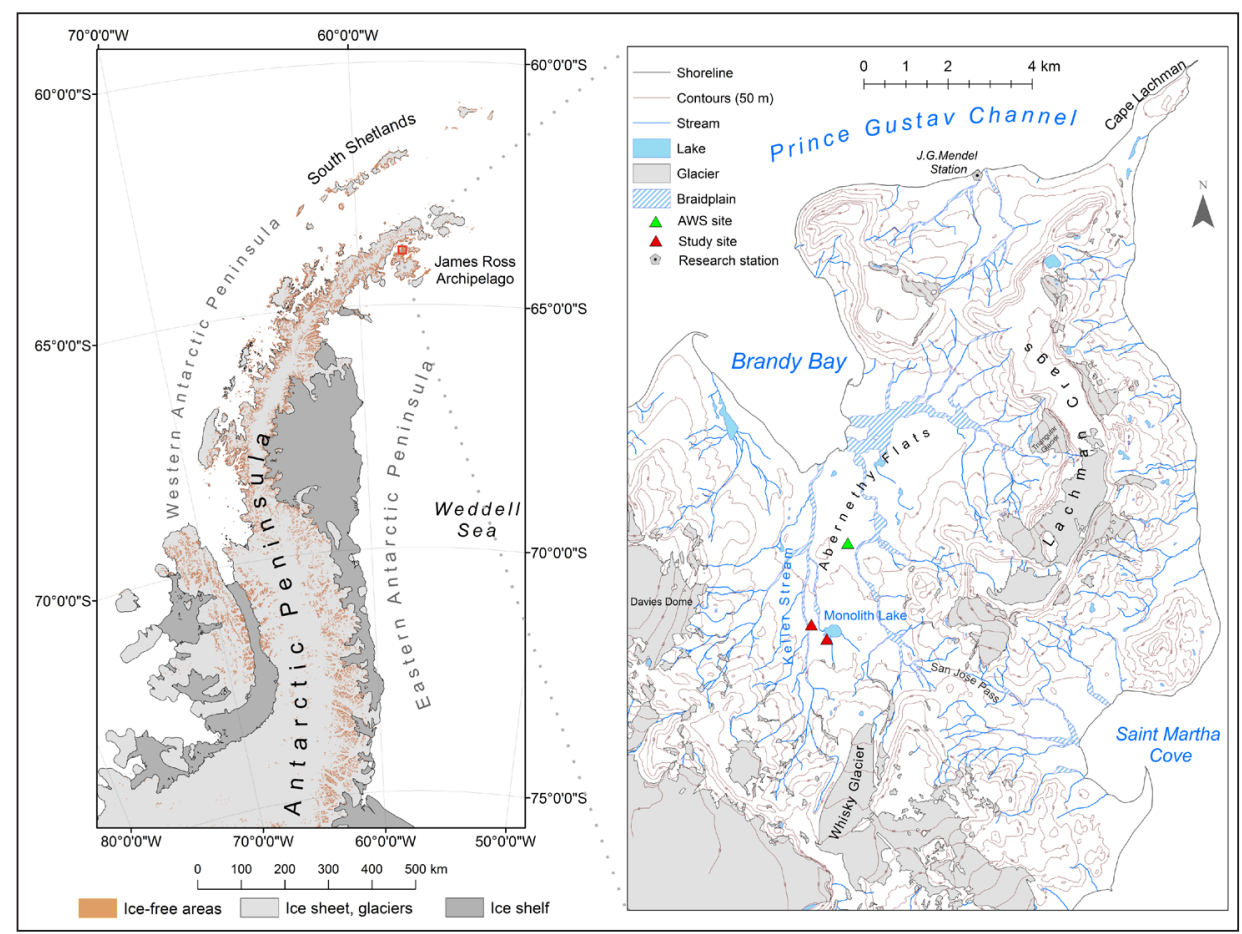

Figure 1. Regional setting and the location of study area on James Ross Island.

\section{Methods}

\subsection{Ground temperature monitoring}

Automatic systems for ground temperature monitoring were installed in January 2017 in close proximity to the two selected boulders of hyaloclastite breccia. The two monitored boulders vary in size. The larger boulder is located close to Monolith Lake, 
with the smaller boulder lying approximately $500 \mathrm{~m}$ to the west of Monolith Lake, next to Keller Stream. Both boulders were selected based on their location, as they were located in relatively flat areas with no other boulders shielding them from the prevailing wind direction. The boulder on the Monolith Lake site is approximately $5 \mathrm{~m}$ high and measures $46.7 \mathrm{~m}$ in circumference. The smaller boulder on the Keller Stream site measures approximately $1.8 \mathrm{~m}$ in height and is $8 \mathrm{~m}$ in circumference. The scheme of ground temperature probe positions can be seen in (Table 1) and (Fig. 2).

Table 1. Distance of the ground temperature probe from the boulder for Monolith Lake and Keller Stream sites in $\mathrm{cm}$.

\begin{tabular}{|l|c|c|c|c|}
\hline & $\mathbf{Z 1}$ & $\mathbf{Z 2}$ & $\mathbf{Z 3}$ & $\mathbf{Z 4}$ \\
\hline M1 & 75 & 175 & 385 & 600 \\
\hline M2 & 75 & 175 & 385 & 600 \\
\hline K1 & 40 & 150 & 380 & - \\
\hline K2 & 40 & 150 & 420 & - \\
\hline
\end{tabular}

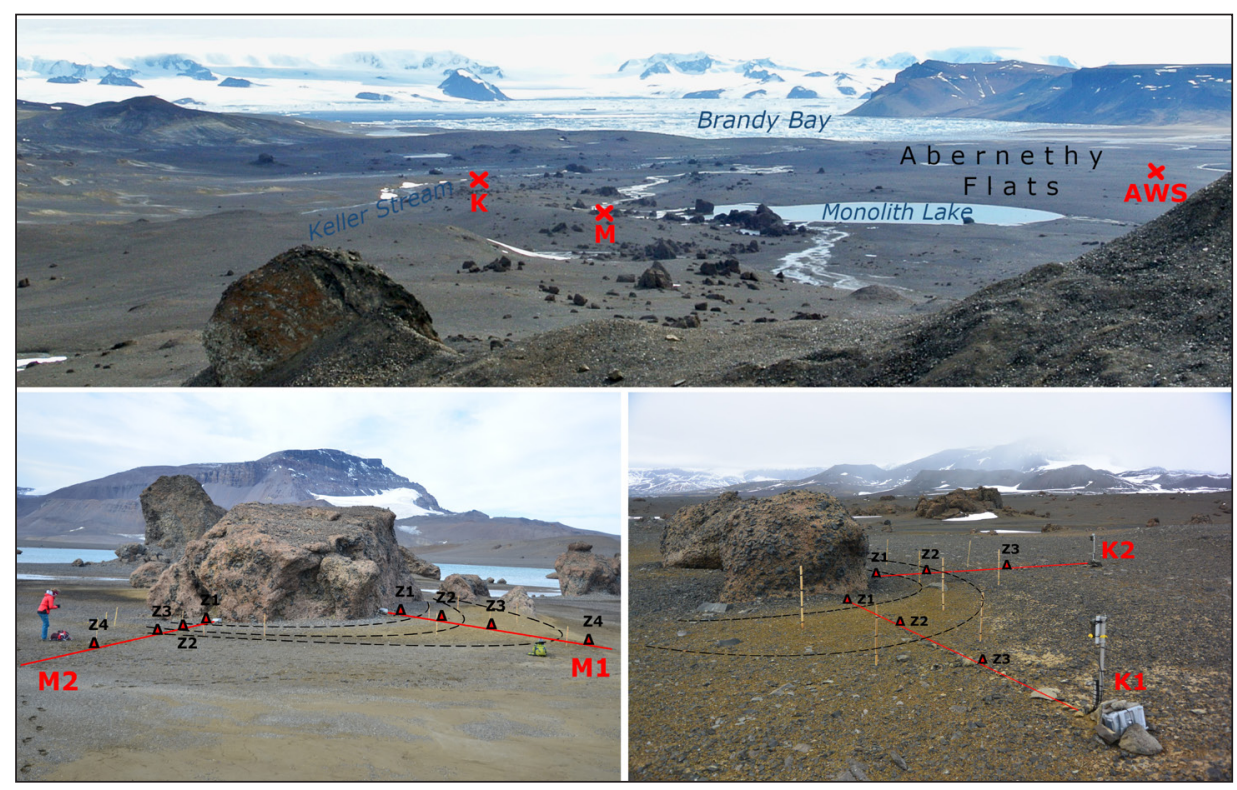

Figure 2. Study area. A panoramic view from the Whisky Glacier moraine towards the hyaloclastite breccia boulder train with Abernethy Flats and Brandy Bay (A), the study sites at the Monolith Lake (B) and Keller Stream (C).

The ground temperature measuring equipment consists of two dataloggers at both the Monolith Lake site (V12 EMS) and at the Keller Stream site (Fiedler MiniLog). Pt100 temperature probes (accuracy $\pm 0.15^{\circ} \mathrm{C}$ ) were installed across transects at various depths 
( $2 \mathrm{~cm}, 5 \mathrm{~cm}$ and $15 \mathrm{~cm}$ for Monolith Lake site; $5 \mathrm{~cm}$ and $15 \mathrm{~cm}$ for Keller Stream site and at various distances from the boulder, see Table 1). The orientation of the primary transect (dataloggers M1 and K1) corresponds to the prevailing local wind direction (azimuth $205^{\circ}$ ), with the secondary transect (dataloggers M2 and K2) orientated perpendicular to the primary transect (azimuth $295^{\circ}$ ). The temperature was measured and recorded every 30 minutes. The data were used for the calculation of mean, maximum and minimum daily temperatures. Additionally, the daily amplitude was used as a marker of snow presence on the site (e.g. Hrbáček et al., 2016; Oliva et al., 2017).

In order to describe ground thermal properties, the thermal indices were calculated, which are commonly used in other studies in both the Arctic and Antarctic (e.g. Frauenfeld et al., 2007). The thermal indices used in this study are:

a) Freezing degree days (FDD) as a sum of mean daily temperatures $<0{ }^{\circ} \mathrm{C}$ of air (FDDa) and $5 \mathrm{~cm}$ depth (FDDg)

b) Thawing degree days (TDD) as a sum of mean daily temperatures $>0{ }^{\circ} \mathrm{C}$ of air (TDDa) and $5 \mathrm{~cm}$ depth (TDDg)

c) The freeze-thaw days with the maximum daily temperature $>0.15^{\circ} \mathrm{C}$ and the minimum daily temperature $<-0.15^{\circ} \mathrm{C}$

d) Isothermal days as days with the daily amplitude $<0.3{ }^{\circ} \mathrm{C}$

The freeze-thaw and isothermal days were defined with a respect to the accuracy of the temperature sensors.

\subsection{Snow cover monitoring}

Both sites have been fitted with trail cameras (LTL Acorn $6310 \mathrm{MCW}$ ), one at the end of each transect, facing towards the boulder. Stakes marked with snow height indicators were placed between the camera and the boulder.

At the Keller Stream site, both trail cameras functioned for the whole year from January 2017 to January 2018, taking photos approximately every 3 hours. At the Monolith Lake site, one of the trail cameras installed on the main transect malfunctioned in mid-June as a result of being buried in a snow drift. The second camera also ceased working for the same reason at the end of June.

\subsection{Field survey}

During January 2017, a field survey was undertaken in the vicinity of the hyaloclastite breccia boulder train. Approximately 50 boulders were selected with the aim of determining their dimensions in relation to the width of the sorted area around the boulder. For each boulder, the following characteristics were recorded using the specified equipment:

- GPS coordinates (Garmin GPSMap 62s handheld GPS device)

- $\quad$ height (Nikon 550 AS distance meter, accuracy $0.1 \mathrm{~m}$ )

- circumference (measuring tape) 
- $\quad$ width of the sorted area (measuring tape)

- geometry of snow accumulations and sorted zones around the boulders (Garmin GPSMap 62s handheld GPS device)

\subsection{Grain size analysis}

Regolith samples were collected from both sites along the main transects, with samples being collected from the surface as well as from a depth of $10 \mathrm{~cm}$ at different distances from the boulder. At the Monolith Lake site, samples were collected from 4 zones (Z1-Z4), and at the Keller Stream site samples were collected from 3 zones.

As a result of logistical reasons, it was not possible to transport large samples of regolith from Antarctica to Europe. Therefore, each sample was dry sieved on site, and only the fraction below $2 \mathrm{~mm}$ was transported for further analysis. Once transported to the laboratory, the samples were processed using a combined laser and camera Bettersize S3 Plus particle size analyser at Polar-Geo-Lab, Department of Geography, Masaryk University in Brno.

For a better overall representation of the sorting processes occurring around the boulders, we also calculated fine-to-coarse sand index, which shows the relative proportion of the two most commonly found fractions.

\subsection{Reference weather station}

The reference automatic weather station (AWS) is located on the Abernethy Flats and provides data for the wider area (Hrbáček et al., 2017). In this study, the data from 01 February 2017 to 31 January 2018 was processed for analysis. The surrounding area of the automatic weather station is formed of an approximately flat surface with slope angles of $<3^{\circ}$, therefore the meteorological parameters measured were not affected by topography and are lithologically analogical to the surroundings of the studied boulders. Air temperature data was measured at $2 \mathrm{~m}$ above the ground by a EMS 33 sensor (accuracy $\pm 0.15^{\circ} \mathrm{C}$ ) mounted in a radiation shield, with the ground temperature at $5 \mathrm{~cm}$ depth measured by Pt100 (accuracy $\pm 0.15^{\circ} \mathrm{C}$ ). Wind speed and direction was measured at $3 \mathrm{~m}$ above the ground by a Young Wind Monitor-HD 05108 (wind speed accuracy $\pm 0.3 \mathrm{~m} \mathrm{~s}^{-1}$; wind direction accuracy \pm 3 degrees), and the snow thickness was measured using a Depth Sensor manufactured by Judd Communication (accuracy $\pm 1 \mathrm{~cm}$ ).

The temperature data were evaluated in an identical way as those from the Monolith Lake and Keller Stream sites. Wind speed, wind direction, and snow thickness data provided information necessary for the evaluation of the boulder's effect on snow accumulation and ground sorting. 


\section{Results}

In the following section the results of the ground temperature monitoring, as well as the snow and wind conditions are presented for the study period. For comparison, data from the reference AWS on the Abernethy Flats is used. Data collected from environmental monitoring is supplemented with field survey, mapping, and laboratory analyses.

\subsection{Ground thermal characteristics}

The mean annual air temperature at the reference site on Abernethy Flats was $-6.6{ }^{\circ} \mathrm{C}$ (Table 2), while the mean daily air temperature varied between $7.4{ }^{\circ} \mathrm{C}$ and $-28.9^{\circ} \mathrm{C}$ (Fig. 3). The warmest month was December 2017 (mean temperature $0.6{ }^{\circ} \mathrm{C}$ ), while the coldest month was June $2017\left(-15.3{ }^{\circ} \mathrm{C}\right)$. TDDa reached $244{ }^{\circ} \mathrm{C} \cdot$ days, FDDa was $-2653{ }^{\circ} \mathrm{C}$-days. The number of air temperature defined freeze-thawing days was 142. Mean annual ground temperature at $5 \mathrm{~cm}$ at the Abernethy Flats site was $-5.9^{\circ} \mathrm{C}$. The mean daily ground temperature varied between $10.5^{\circ} \mathrm{C}$ and $-19.4{ }^{\circ} \mathrm{C}$. TDDg was $480{ }^{\circ} \mathrm{C} \cdot$ days, FDDg dropped to $-2638{ }^{\circ} \mathrm{C} \cdot$ days. The total number of freeze-thawing days at $5 \mathrm{~cm}$ was 81 , while the number of isothermal days at $5 \mathrm{~cm}$ was 35 .

Table 2. Air and ground thermal characteristics at the Abernethy Flats AWS.

\begin{tabular}{|l|l|}
\hline \multicolumn{1}{|c|}{ Parameter } & \multicolumn{1}{c|}{ Value } \\
\hline MAAT $\left({ }^{\circ} \mathrm{C}\right)$ & -6.6 \\
\hline MAGT $5 \mathrm{~cm}\left({ }^{\circ} \mathrm{C}\right)$ & -5.9 \\
\hline TDDa $\left({ }^{\circ} \mathrm{C} \cdot\right.$ day $)$ & 244 \\
\hline TDDg $\left({ }^{\circ} \mathrm{C} \cdot\right.$ day $)$ & 480 \\
\hline FDDa $\left({ }^{\circ} \mathrm{C} \cdot\right.$ day $)$ & -2653 \\
\hline FDDg $\left({ }^{\circ} \mathrm{C} \cdot\right.$ day $)$ & -2638 \\
\hline F-T days air & 142 \\
\hline F-T days $5 \mathrm{~cm}$ & 81 \\
\hline IT days $5 \mathrm{~cm}$ & 35 \\
\hline
\end{tabular}

The mean annual ground temperature at the Monolith Lake site varied between -6.7 and $-5.4{ }^{\circ} \mathrm{C}$ within the main transect (M1), and between -6.5 and $-5.5{ }^{\circ} \mathrm{C}$ within the secondary transect (Fig. 3). There were only very slight differences in mean ground temperature between the three monitored depths (Table 3). In the main transect, the lowest mean annual ground temperatures occurred closest to the boulder in Z1, increased towards Z2, and then decreased slightly in Z3 and Z4. In the secondary transect, the lowest temperatures occurred at the furthest distance from the boulder and increased in the direction towards the boulder. The mean daily ground temperature amplitude in M1 decreased away from the boulder and also with depth. The maximum and minimum 


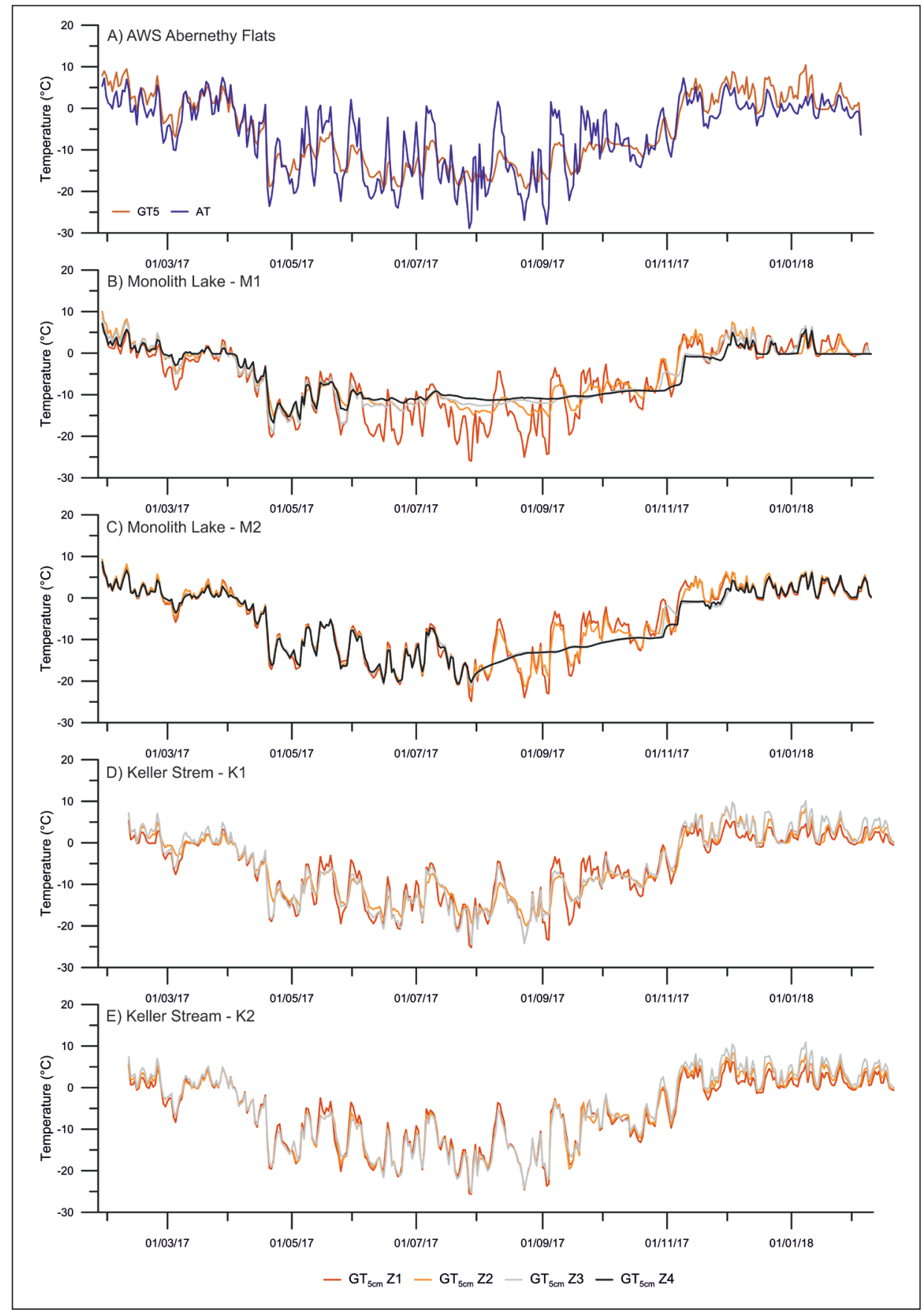

Figure 3. Variability of air temperature (AT) and ground temperature $(G T)$ at selected depths at the Abernethy Flats reference site and Monolith Lake and Keller Stream study sites in the zones $1-4(Z 1-Z 4)$. 
Table 3. Ground thermal characteristics at the Monolith Lake site.

\begin{tabular}{|c|c|c|c|c|c|c|c|c|}
\hline \multirow{2}{*}{ Parameter } & \multicolumn{4}{|c|}{ Monolith Lake 1} & \multicolumn{4}{|c|}{ Monolith Lake 2} \\
\hline & $\mathbf{Z 1}$ & $\mathbf{Z 2}$ & $\mathbf{Z 3}$ & $\mathbf{Z 4}$ & $\mathbf{Z 1}$ & $\mathbf{Z 2}$ & $\mathbf{Z 3}$ & $\mathbf{Z 4}$ \\
\hline MAGT $2 \mathrm{~cm}\left({ }^{\circ} \mathrm{C}\right)$ & -6.6 & -5.4 & -5.9 & -5.7 & -5.5 & -6.2 & -6.2 & -6.5 \\
\hline MAGT $5 \mathrm{~cm}\left({ }^{\circ} \mathrm{C}\right)$ & -6.7 & -5.4 & -5.7 & -5.6 & -5.8 & -5.7 & -6.2 & -6.3 \\
\hline MAGT $15 \mathrm{~cm}\left({ }^{\circ} \mathrm{C}\right)$ & -6.5 & -5.4 & -5.7 & -5.5 & -5.6 & -5.7 & -6.3 & -6.3 \\
\hline GTA $2\left({ }^{\circ} \mathrm{C}\right)$ & 6.1 & 4.0 & 4.4 & 3.5 & 7.1 & 7.9 & 4.3 & 3.8 \\
\hline $\operatorname{GTA} 5\left({ }^{\circ} \mathrm{C}\right)$ & 4.8 & 2.6 & 2.4 & 1.5 & 4.5 & 4.3 & 2.6 & 2.6 \\
\hline GTA $15\left({ }^{\circ} \mathrm{C}\right)$ & 2.7 & 1.5 & 1.1 & 0.9 & 2.7 & 2.4 & 1.8 & 1.6 \\
\hline TDD $5\left({ }^{\circ} \mathrm{C} \cdot\right.$ day $)$ & 240 & 288 & 232 & 152 & 348 & 397 & 292 & 289 \\
\hline FDD $5\left({ }^{\circ} \mathrm{C} \cdot\right.$ day $)$ & -2768 & -2313 & -2391 & -2259 & -2521 & -2546 & -2611 & -2648 \\
\hline IT days 2 & 2 & 63 & 139 & 163 & 0 & 0 & 46 & 56 \\
\hline IT days 5 & 2 & 73 & 149 & 186 & 0 & 0 & 51 & 69 \\
\hline IT days 15 & 21 & 97 & 184 & 205 & 4 & 6 & 54 & 64 \\
\hline F-T days 2 & 115 & 72 & 89 & 82 & 118 & 138 & 68 & 99 \\
\hline F-T days 5 & 77 & 22 & 24 & 31 & 73 & 24 & 33 & 56 \\
\hline F-T days 15 & 30 & 11 & 8 & 11 & 35 & 6 & 18 & 50 \\
\hline
\end{tabular}

amplitudes were $6.1{ }^{\circ} \mathrm{C}$ and $3.5^{\circ} \mathrm{C}$ in $\mathrm{Z} 1$ and $\mathrm{Z} 4$, respectively. A similar pattern was observed also in M2, with amplitudes reaching slightly higher than in M1, with the maximum and minimum amplitudes being $7.9^{\circ} \mathrm{C}(\mathrm{Z} 2)$ and $1.6^{\circ} \mathrm{C}(\mathrm{Z} 4)$, respectively. The number of isothermal days increased away from the boulder. There were only 2 isothermal days observed in the main transect in $\mathrm{Z} 1$ close to the ground surface, in contrast to 163 such days in $\mathrm{Z} 4$. The number of isothermal days also increased greatly with depth. Approximately one third of the total amount of isothermal days were observed in Z3 and Z4 on the secondary transect; however, in Z1 and Z2 no isothermal days at 2 and $5 \mathrm{~cm}$ depths were detected. The number of freeze-thaw days in Z1 was similar in both transects. The frequency of freeze-thaw cycles decreased with depth. The maximum number of freeze-thaw days (138) was observed in Z2 in the secondary transect, closest to ground surface. The minimum (6) was within the same zone, at $15 \mathrm{~cm}$ below ground surface (Fig. 4). TDDg was between 152 and $288^{\circ} \mathrm{C} \cdot$ days within the primary transect, and between 289 and $397^{\circ} \mathrm{C}$-days in the secondary transect. FDDg dropped to between -2259 and $-2768^{\circ} \mathrm{C} \cdot$ days (primary transect) and -2521 and $-2648^{\circ} \mathrm{C} \cdot$ days (secondary transect). 


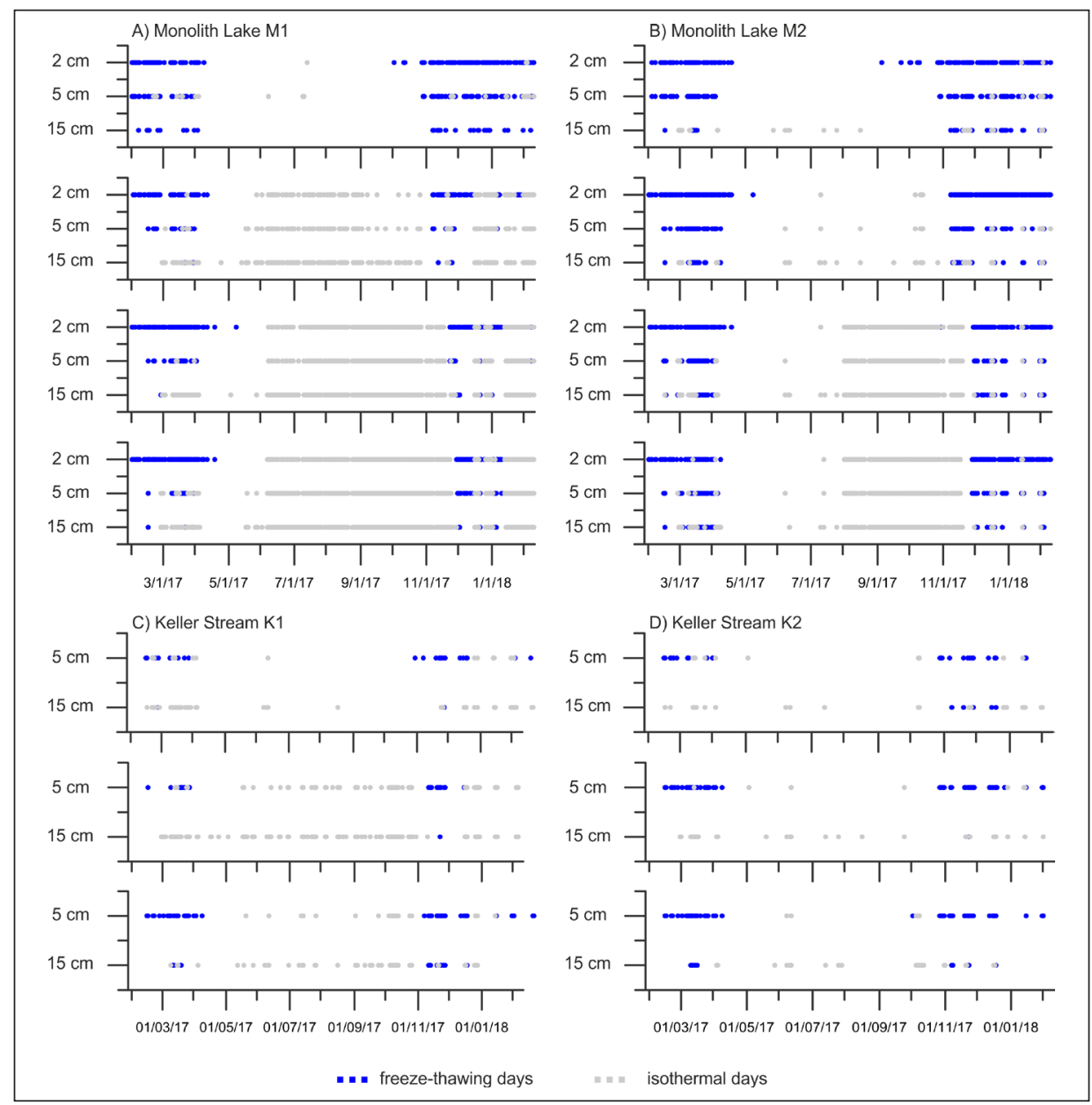

Figure 4. Calendar of freeze-thawing days and isothermal days at the Monolith Lake and Keller Stream sites.

At the Keller Stream site, mean annual ground temperature decreased away from the boulder in both transects. Overall, in the comparison between the two transects, there were very similar averages for all zones, with the maximum difference being only $0.2^{\circ} \mathrm{C}$ in Z2 (Table 4 and Fig. 3). Greater differences between the two transects can be seen in mean daily ground temperature amplitude. This is slightly higher in all zones of K2. The amplitude in $\mathrm{K} 2$ increases away from the boulder; however, in K1, the minimum amplitude is observed in Z2. The number of isothermal days is higher in K1, where most such days occur in Z2. The number of isothermal days increases with depth. The occurrence of freezethaw days is higher in the secondary transect, especially in Z2, where 55 freeze-thawing days were observed at a depth of $5 \mathrm{~cm}$, in comparison to only 19 freeze-thawing days in the main transect. In Z1 and Z3, the total number of freeze-thawing days is similar for both 
Table 4. Ground thermal characteristics at the Keller Stream site.

\begin{tabular}{|c|c|c|c|c|c|c|}
\hline \multirow{2}{*}{ Parameter } & \multicolumn{3}{|c|}{ Keller Stream 1} & \multicolumn{3}{|c|}{ Keller Stream 2} \\
\hline & $\mathbf{Z 1}$ & $\mathbf{Z 2}$ & $\mathbf{Z 3}$ & $\mathbf{Z 1}$ & $\mathbf{Z 2}$ & $\mathbf{Z 3}$ \\
\hline MAGT $5 \mathrm{~cm}\left({ }^{\circ} \mathrm{C}\right)$ & -5.4 & -5.6 & -6.2 & -5.3 & -5.8 & -6.1 \\
\hline MAGT $15 \mathrm{~cm}\left({ }^{\circ} \mathrm{C}\right)$ & -5.4 & -5.6 & -6.1 & -5.4 & -5.7 & -6.1 \\
\hline GTA $5 \mathrm{~cm}\left({ }^{\circ} \mathrm{C}\right)$ & 4.1 & 3.1 & 5.4 & 4.8 & 5.5 & 6.1 \\
\hline GTA $15 \mathrm{~cm}\left({ }^{\circ} \mathrm{C}\right)$ & 2.3 & 1.7 & 2.8 & 2.7 & 2.8 & 3.0 \\
\hline TDD $5 \mathrm{~cm}\left({ }^{\circ} \mathrm{C} \cdot\right.$ day $)$ & 197 & 332 & 435 & 235 & 360 & 508 \\
\hline FDD $5 \mathrm{~cm}\left({ }^{\circ} \mathrm{C} \cdot\right.$ day $)$ & -2575 & -2490 & -2553 & -2575 & -2662 & -2588 \\
\hline IT days 5 & 8 & 34 & 14 & 5 & 4 & 10 \\
\hline IT days 15 & 34 & 60 & 27 & 20 & 20 & 18 \\
\hline F-T days 5 & 24 & 19 & 45 & 27 & 55 & 51 \\
\hline F-T days 15 & 3 & 1 & 13 & 5 & 1 & 10 \\
\hline
\end{tabular}

transects. However, fewer freeze-thawing days were observed at a depth of $15 \mathrm{~cm}$ than were observed at a depth of $5 \mathrm{~cm}$ (Fig. 4). TDDg on the Keller Stream site was between 197 and $435^{\circ} \mathrm{C}$-days within the primary transect, and between 235 and $508{ }^{\circ} \mathrm{C} \cdot$ days in the secondary transect, with FDDg dropping to between -2490 and $-2575{ }^{\circ} \mathrm{C} \cdot$ days (primary transect) and -2575 and $-2662{ }^{\circ} \mathrm{C} \cdot$ days (secondary transect).

\subsection{Snow accumulation}

Continuous snow cover at the reference site on the Abernethy Flats occurred between the beginning of May and the beginning of November 2017 (Fig. 5). The mean thickness of the snow was $19 \mathrm{~cm}$, with the maximum thickness in mid-October reaching $50 \mathrm{~cm}$. The data from the time-lapse camera at the Monolith Lake site showed a rapid snow accumulation between mid-May and the beginning of June, during which time the maximum snow thickness around the boulder increased from 20 to $70 \mathrm{~cm}$ (Fig. 5). The minimum thickness at the margin of the snow accumulation corresponds with the snow thickness measured at the Abernethy Flats site. At the Keller Stream site, the snow accumulation starts to develop in early March. At this site, the snow thickness corresponds to those observed at the Abernethy Flats site; however, there were more peaks indicating the snow accumulation forming. Unlike the Monolith Lake site, the snow thickness at the Keller Stream site never exceeded $50 \mathrm{~cm}$ (Fig. 5). 


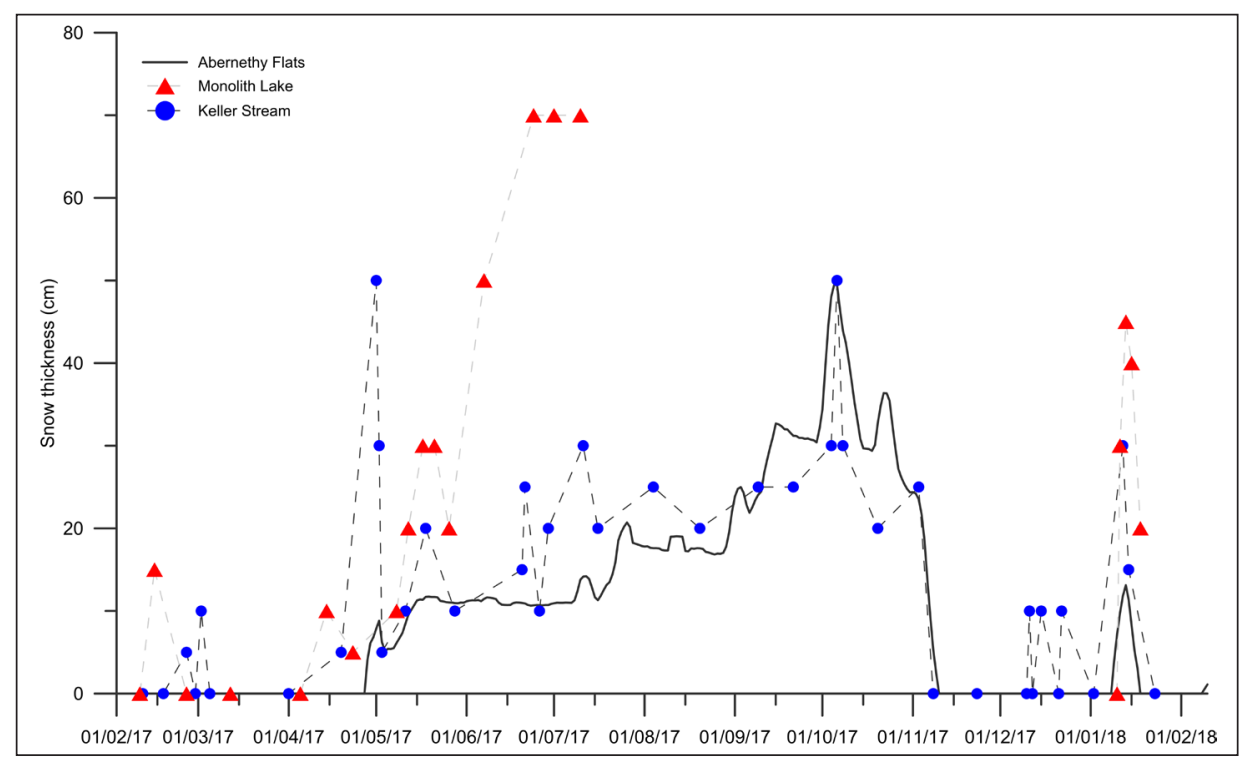

Figure 5. Evolution of snow cover at the Abernethy Flats reference site, Monolith Lake and Keller Stream sites.

\subsection{Wind conditions}

The most common wind direction azimuths at the reference weather station were between $210^{\circ}$ and $240^{\circ}(25.5 \%)$ and between $240^{\circ}$ and $270^{\circ}(12.6 \%)$, which account for $38.1 \%$ of the total wind directions for $60^{\circ}$ span (Fig. 6). The mean wind speed was $5.3 \mathrm{~m} \mathrm{~s}^{-2}$, however it varied significantly with the wind direction. The highest wind speeds which exceeded $20 \mathrm{~ms}^{-2}$ were observed for the azimuth $210^{\circ}$ to $240^{\circ}$, while the lowest wind speeds that rarely exceeded $5 \mathrm{~ms}^{-2}$ were from $150^{\circ}$ to $210^{\circ}$ (Fig. 6).

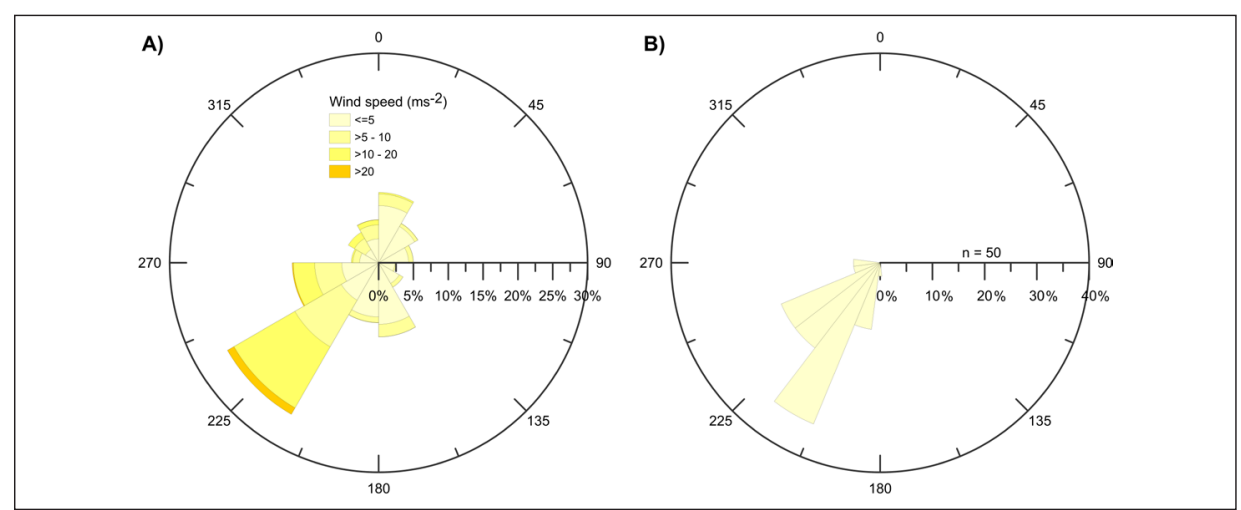

Figure 6. Variability of wind speed and wind direction at Abernethy Flats (A) and the azimuths of the sorted rims around the boulders $(B)$. 


\subsection{Geometry of sorted zone around the boulders}

The prevailing wind direction in the area was assumed from the geometry of the snow accumulations created on windward sides of the boulders. The sorted zones around the boulders also have slightly elongated geometries, with the main axis orientated towards the prevailing wind direction. The most frequent azimuths were observed between $210^{\circ}$ and $225^{\circ}(33.3 \%)$, with all the azimuths of the monitored boulders orientated between $180^{\circ}$ and $270^{\circ}$ (Fig. 6).

A close relationship was discovered between boulder morphometry and the width of the longest axis of the sorted zone. Strong logarithmical correlation $(\mathrm{r}=$ 0.88 ) significant at $\mathrm{p}<0.01$ (Fig. 7) was observed between the circumference of the boulder and the width of the sorted rim. The logarithmical correlation between the boulder height and the width of the sorted zone was slightly weaker $(r=0.81)$, but also significant at $\mathrm{p}<0.01$ (Fig. 7).

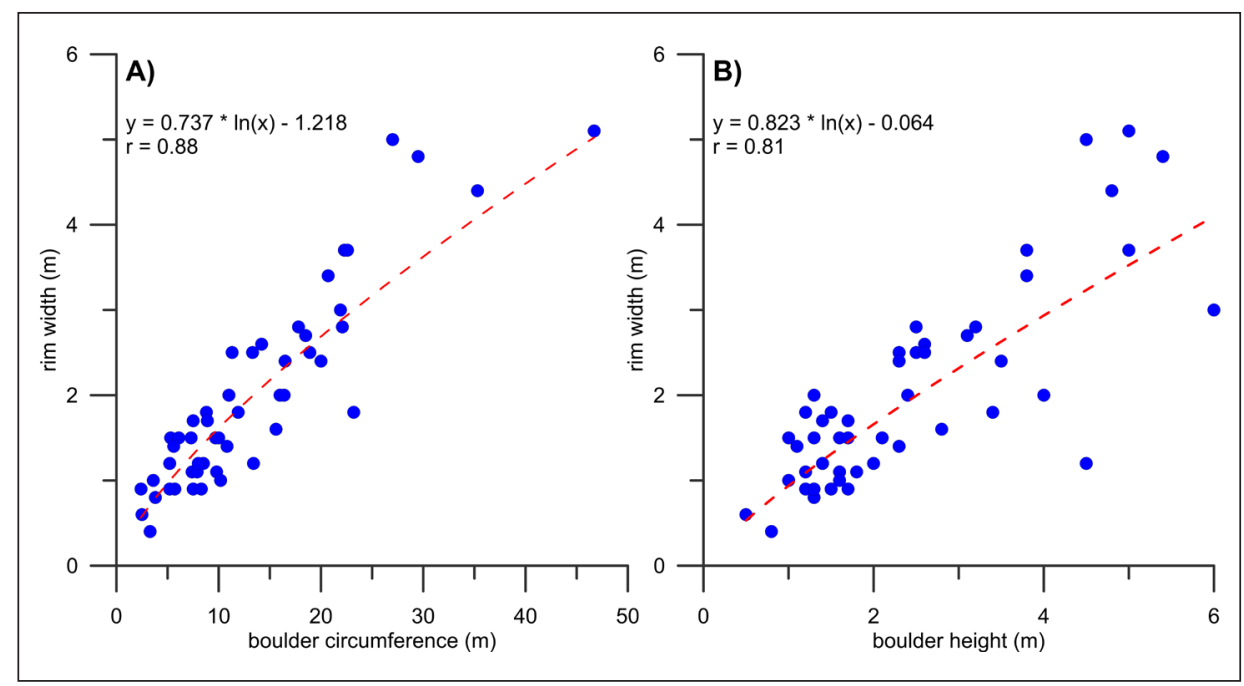

Figure 7. Relationship of sorted rim width to boulder circumference (A) and to boulder height (B).

\subsection{Grain size analysis}

Grain size analyses of samples from the Monolith Lake site show very low and relatively stable distributions of clay and silt within the whole transect. The most significant differences between the individual zones can be seen in the fine sand fraction, the share of which increases significantly with distance from the boulder, peaking in $\mathrm{Z} 3$ and subsequently decreasing again towards $\mathrm{Z} 4$. The maximum share of the fine sand fraction reaches almost $65 \%$ in $\mathrm{Z3}$ at a depth of $10 \mathrm{~cm}$ (Fig. 8). Subsequently, the amount of coarse sand decreases outwards from its maximum in Z1 towards Z3, then increases again in Z4. The share of fine fractions up to medium sand is higher at $10 \mathrm{~cm}$ below the surface than at the surface in all the zones. However, this 


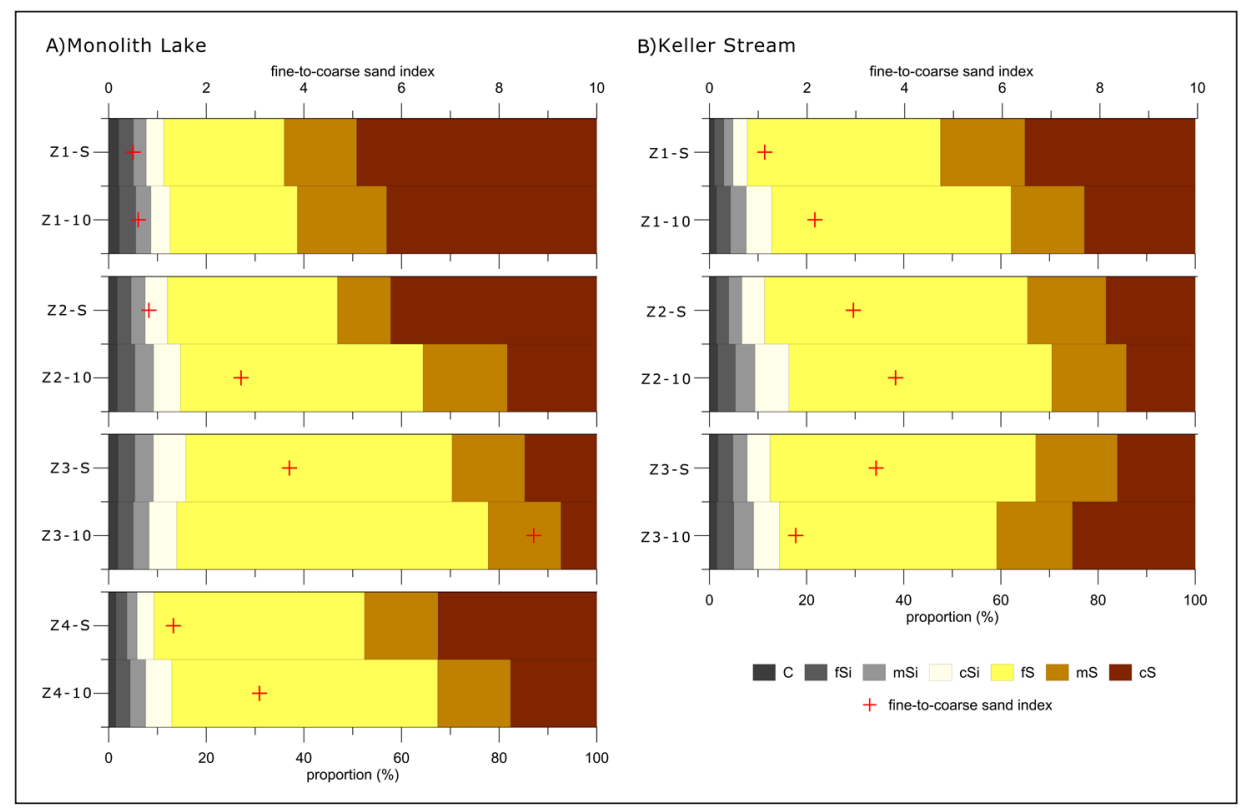

Figure 8. Grain size analysis results for the Monolith Lake (A) and Keller Stream (B) sites.

difference is most pronounced in $\mathrm{Z} 2$. The fine-to-coarse sand index increases from $\mathrm{Z} 1$ to $\mathrm{Z3}$, where there is almost $9 \mathrm{x}$ higher proportion of fine sand when compared to coarse sand. In Z4, the fine-to-coarse sand index decreases to approximately 3 at a depth of $10 \mathrm{~cm}$ (Fig. 8).

The Keller Stream site shows a similar pattern to that of the Monolith Lake site (Fig. 8). The most abundant fraction, comprising $>50 \%$ in $\mathrm{Z} 2$, is fine sand, but its increase is not as pronounced as at the Monolith Lake site. The proportion of clay is very low overall, accounting for less than $2 \%$ (Fig. 8). Similarly, the silt share is also negligible. The differences between the two depths also show slightly coarser material composition on the surface in $\mathrm{Z} 1$ and $\mathrm{Z} 2$; however, this is not the case in Z3, where the deeper sample is coarser. The fine-to-coarse sand index is lower compared to the Monolith Lake site and it reaches the highest values in Z2 (Fig. 8).

\section{Discussion}

The breccia boulders represent unique landforms in the central flats of the Ulu Peninsula, James Ross Island. As natural obstacles to wind-transported material, such as snow and sand, they strongly affect wind flow and the accumulation of material around themselves. Therefore, they represent important geomorphological features, which significantly change the formation of micro- to meso-scale landforms in semi-arid periglacial environments. 


\subsection{Ground thermal effect on material sorting}

Ground thermal conditions are one of the most important parameters studied in periglacial environments (e.g. Frauenfeld et al., 2007). The ground temperature monitoring around the breccia boulders and its comparison with the reference AWS site at the Abernethy Flats is therefore important for understanding the specific physical processes associated with the meso-scale periglacial landsystems found around the boulders.

The ground thermal conditions around the breccia boulders differ in some parameters when compared to the AWS at the Abernethy Flats. The main impact that the boulders had on ground thermal regime was caused by the shadowing effect of the boulders that prevented some of the summer incoming radiation reaching the ground, reducing an important input for ground thermal balance (e.g. Smith and Riseborough, 1996), as well as inducing increased snow accumulation around them. Unlike flat areas on James Ross Island, where snow thickness is usually less than $30 \mathrm{~cm}$ and its effect on ground thermal regime is not very significant (Hrbáček et al., 2016), snow accumulation around breccia boulders can exceed $40 \mathrm{~cm}$ for longer periods of time. Such thickness is considered sufficient to cause the isothermal regime of the ground (Zhang et al., 2005).

The effect of the above-mentioned factors is well demonstrated in thawing and freezing degree day indices. The shadowing effect of the boulders was most pronounced in the primary transects and zones closest to the breccia boulders, where TDDg reached the lowest values of approximately 40-50\% lower than at the reference AWS on the Abernethy Flats. In the marginal zones, low values of TDDg were affected by snow accumulation, which caused a shorter thawing period (e.g. Zhang et al., 2005; Oliva et al., 2017). Conversely, in the Z3 zone of both transects from the Keller Stream site, TDDg were very close (K1) or even higher (K2) than on the Abernethy Flats (Table 2). This suggests that these parts of transects were not affected by either the boulder shadowing or the snow accumulation.

The most pronounced effect of the snow was observed in the primary transects, particularly at Z3 and Z4 zones of the Monolith Lake site. Despite the hiatus in snow data for the majority of the winter, the available measurements demonstrate that the snow thickness reached at least $70 \mathrm{~cm}$, and that snow cover exceeding $40 \mathrm{~cm}$, which corresponds to the occurrence of isothermal days, persisted for more than 150 days (Fig. 4).

During the summer months when the area is snow-free, the thermal regime is typical, with high occurrence of freeze-thawing days, which are most frequent at the surficial $2 \mathrm{~cm}$ depth in all transects. Areas with this type of thermal regime that have high moisture contents from the thawing of snow, creates suitable conditions for ground sorting. As a result, sorted rims are commonly found around the breccia boulders.

\subsection{Wind-conditioned snow and sand accumulation}

In cold semi-arid climates, such as that found in the ice-free areas of James Ross Island, frost and snow are very important factors affecting landscape-forming processes. 
Snowfall is generally redistributed by strong winds (e.g. Nývlt et al., 2016). This leads to snow filling topographic depressions; however, a substantial portion of snow also accumulates on the windward and lee sides of obstacles in the form of large drifts. The remaining snow is blown towards the lowest altitudes and commonly accumulates on sea-ice during the winter, or is deposited into the open sea during the summer. The drift surfaces may also bear sastrugi that resemble similar shapes as sand dunes. Tsoar (2001) describes the types of dunes controlled by topographical obstacles such as cliff faces, boulders etc. The airflow streamlines are forced to separate when they hit the front of the obstacle. The front and sides of the obstacle are therefore the most heavily eroded parts. On the windward side, an echo dune is formed of either sand or, in this case, wind-blown snow. Shaped as a semicircle in plan view, its windward slope has a convex profile, with a steep lee slope. Furthermore, a lee dune is created on the lee side of the obstacle.

The shape of the echo dune and, subsequently, the sorted zone around the boulder, is not perfectly circular, but is slightly elongated along the main axis pointing in the prevailing wind direction (Fig. 9). The prevailing azimuths of the sorted rims around the boulders (Fig. 6), which also represent the azimuths of the snow accumulations, corresponds well with prevailing wind direction on the northern Ulu Peninsula (Kavan et al., 2018). Prevailing south-southwestern wind directions are deviated by up to $90^{\circ}$ as a result of comparatively large-scale topography (for example, in the San Jose Pass, or near to Triangular Glacier). In a similar way, the wind direction varies around the boulders, especially where the boulders are clustered in a small area, which therefore affects the airflow direction between them. The direction from which the material is transported by wind in the Abernethy Flats corresponds well $\left(\mathrm{r}^{2}=0.55 ; \mathrm{p}<0.01\right)$ with prevailing wind direction (Fig. 6).

The most common fraction in the sorted rim around the hyaloclastite breccia boulders is fine sand $(0.063-0.250 \mathrm{~mm})$. This fraction is most easily entrained by wind, as it is not as

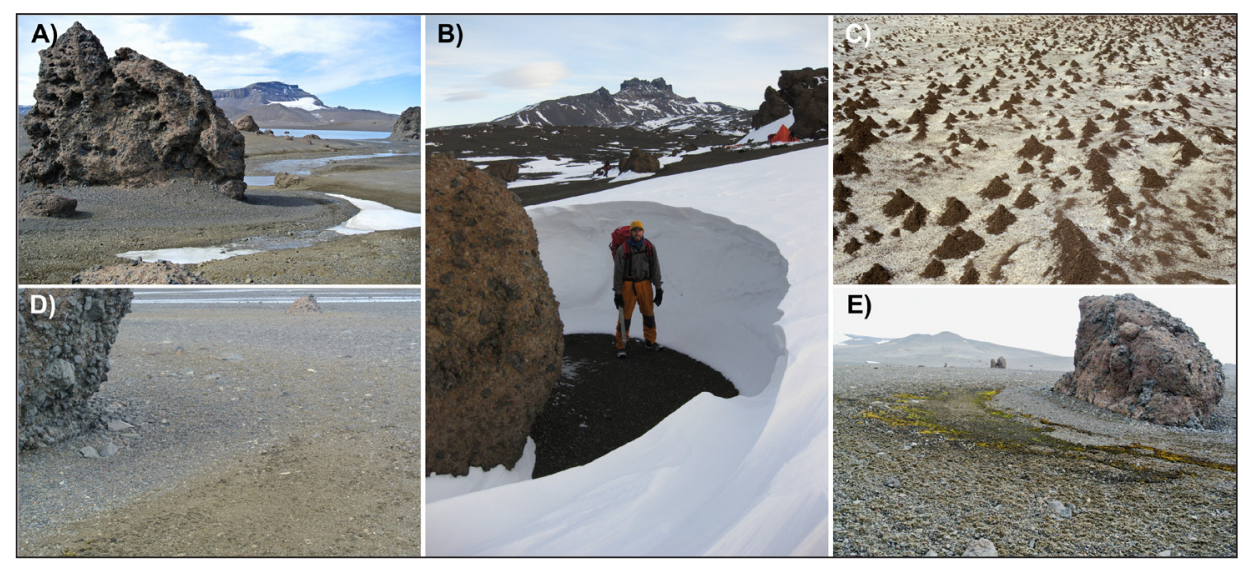

Figure 9. Periglacial-aeolian landsystem evolution. Hyaloclastite breccia boulder during the summer with the remnants of an oval-shaped snow accumulation $(A)$, large snow accumulation with standing person for scale $(B)$, detail of wind-blown sand on the surface of the snow $(C)$, detail of ground sorting around the boulder $(D)$, vegetation cover in the proximity of the boulder $(E)$. 
electrostatically and molecularly cohesive as clay or silt particles, but is still light enough compared to coarser fractions to be entrained and transported by the wind in suspension. Saltation induced by bombardment of already wind-transported particles, represents the other important process of sand grain entrainment by the wind (Thomas, 1997).

The limiting factors of aeolian sediment transport are usually sediment supply, to a lesser extent wind speed (Lancaster, 2002), and also surface moisture (McKenna Neuman, 2004; Wiggs, 2004). Surface moisture was reported as an important factor limiting the amount of fine-grained material entrainment by wind and its subsequent transport on James Ross Island, with a higher probability of aeolian transport at the end of summer season when surface moisture is at its minimum (Kavan et al., 2018). Accumulation of snow as a result of the presence of boulders, plays an important role in the subsequent deposition of fine sandy material on the windward and lee sides of the boulders. The adhesion of a wet surface of snow (or later melt-water) is certainly greater than of the surrounding relatively dry surface, thus leading to higher accumulation rates on snow surfaces (Fig. 9).

Apart from the depositional processes on the windward and lee side of boulders, the effect of melting snow on local microecosystems is directly connected to the boulder surface and its immediate vicinity (Fig. 9). The boulders are often inhabited by lichens or algal/cyanobacterial crusts where conditions are favourable and the communities are protected from the wind (Balks and $\mathrm{O}^{\prime} \mathrm{Neill}, 2016$ ). Also, ground moisture is substantially higher on the windward and lee sides of the boulders, as a result of meltwater originating from the accumulated snow. This results in a greater abundance of mosses and lichens, and presumably also algae and cyanobacteria. This localised nature of colonisation resembles colonisation around seal carcasses that are spread around the ice-free area of Ulu Peninsula (Nývlt et al., 2016).

\subsection{Meso-scale periglacial-aeolian landsystem around the hyaloclastite breccia boulders}

The origin of specific meso-scale landsystems driven by periglacial and aeolian processes that evolved around the boulders of hyaloclastite breccia, can be presented in a three-step development model (Fig. 10).

a) Hyaloclastite breccia boulder train deposition. The boulders were transported to their present position by the Late-Holocene advance of Whisky Glacier (Davies et al., 2013, 2014) and deposited when the glacier receded. The boulders must have been supraglacially transported as the hyaloclastite breccia would have easily disintegrated if transported subglacially or englacially. This phase represents the only stage where glacial processes dominate the landscape formation. Physical weathering including freeze-thaw induced disintegration of the boulder surfaces produced coarse-grained weathering rims around the boulders (Fig. 10).

b) Snow and sand accumulations around the breccia boulders. The hyaloclastite breccia boulders act as natural obstacles for the prevailing south to southwestern 
winds, allowing snow to accumulate in elongated shapes around the boulders with the echo and lee dunes being the highest (Fig. 10). Subsequently, dry winds transporting loose material from the ice-free surface of the Abernethy Flats (Kavan et al., in prep.) deposit fine sand on the surface of snow accumulations (cf. Fig. 10). The snow cover around the boulders effectively insulates the

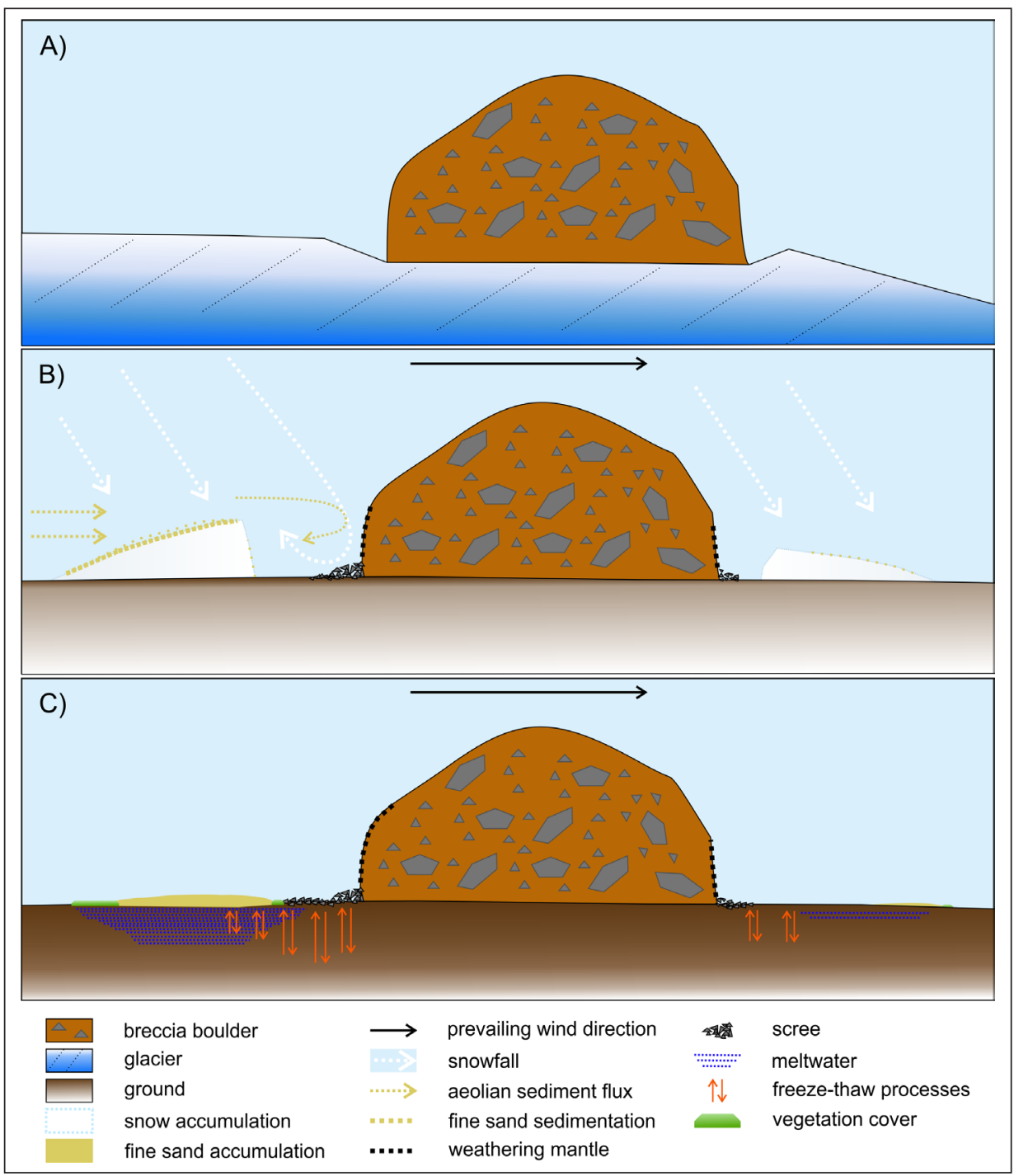

Figure 10. Three-step development model of a meso-scale periglacial and aeolian landsystem around the hyaloclastite breccia boulder. The boulder is transported supraglacially $(A)$, the winter situation with snow accumulation forming on the windward side $(B)$, the summer situation with fine sand accumulation and vegetation cover $(C)$. 
active layer, inducing an isothermal ground regime (Zhang et al., 2005). This is important as snow accumulation in the flat areas of James Ross Island is generally limited (Hrbáček et al., 2016), and therefore isothermal ground regimes do not widely occur.

c) Snow melting and formation of sorted rims around breccia boulders. After the melting of snow accumulations around the hyaloclastite breccia boulders, the fine sand released from the snow deposits in the windward sector of the boulders making a well-developed rim of sorted fine material (Fig. 10). This is further enhanced by freeze-thaw processes associated with increased moisture in the surrounding of boulders. The width and distance of the sorted rim from the hyaloclastite boulder corresponds with the width of the boulder (represented in our case by the measured circumference) and less importantly with the height of the boulder (Fig. 7). Continuous melting of accumulated snow also develops specific niches for colonisation by mosses and lichens (Fig. 10).

\section{Conclusions}

In this paper, a three-step development model of a meso-scale periglacial and aeolian landsystem, which is specific for the arid to semi-arid environment within the Antarctic Peninsula region, has been presented. The hyaloclastite breccia boulder train located in the central part of Ulu Peninsula presents a unique opportunity to study periglacial and aeolian processes at a micro- to meso-scale. The hundreds of large and small boulders, forming a $5-\mathrm{km}$ long belt, mainly act as obstacles to the prevailing wind, causing snow to accumulate in dune-like drifts on their windward and lee sides. Normally, the snow is blown away from the flat surfaces of James Ross Island, and limited snow thickness has generally been observed on such surfaces. The snow accumulations are well-developed in the south to southwestern sector of the boulders, aligned with the direction of the snow-bringing winds that come during the winter. The presence of snow significantly affects the thermal and hydric regime of the underlying permafrost and active layer. Thick layers of snow decrease the ground temperature and increase the number of isothermal days, while the number of freeze-thaw cycles is reduced. The adhesive surface of snow also acts as a trap for the particles of wind-blown fine sand, producing fine-grained rims around the windward and lee sides of the boulders. Water content of the ground is often a limiting factor for biota development in the otherwise semi-arid climate of James Ross Island. Meltwater from the accumulated snow presents a unique source of moisture, and enables moss and lichen colonization in the vicinity of the boulders. The hyaloclastite breccia boulders can therefore be considered a significant agent for the creation of localised favourable biotic conditions.

\section{Acknowledgements}

Research was supported by Ministry of Education, Youth and Sports of the Czech Republic projects LM2015078 and Z.02.1.01/0.0/0.0/16_013/0001708 and by the Masaryk University project MUNI/A/1251/2017. We thank Stephen J.A. Jennings for his contribution regarding proofreading of the manuscript. 


\section{References}

Altunkaynak, Ş., Aldanmaz, E., Güraslan, I.N., Çalışkanoğlu, A.Z., Ünal, A., Nývlt, D. 2018. Lithostratigraphy and petrology of Lachman Crags and Cape Lachman lava-fed deltas, Ulu Peninsula, James Ross Island, north-eastern Antarctic Peninsula: Preliminary results. Czech Polar Reports 8 (1), 60-83.

Atkins, C.B., Dunbar, G.B. 2009. Aeolian sediment flux from sea ice into Southern McMurdo Sound, Antarctica. Global and Planetary Change 69 (3), 133-141. https://doi.org/10.1016/j. gloplacha.2009.04.006.

Ayling, B.F., McGowan, H.A. 2006. Niveo-eolian sediment deposits in coastal South Victoria Land, Antarctica: Indicators of regional variability in weather and climate. Arctic, Antarctic and Alpine Research 38 (3), 313-324. https://doi.org/10.1657/1523-0430(2006)38[313:NSD ICS]2.0.CO;2.

Balks, M.R., O'Neill, T.A. 2016. Soil and permafrost in the Ross Sea region of Antarctica: stable or dynamic? Cuadernos de Investigación Geográfica 42 (2), 415-434. https://doi.org/10.18172/ cig.2923.

Benn, D.I., Evans, D.J.A. 2010. Glaciers and Glaciation. $2^{\text {nd }}$ Edition. 802 pp., Hodder Arnold Publication, London.

Björck, S., Olsson, S., Ellis-Evans, C., Håkansson, H., Humlum, O., de Lirio, J.M. 1996. Late Holocene palaeoclimatic records from lake sediments on James Ross Island, Antarctica. Palaeogeography, Palaeoclimatology, Palaeoecology 121 (3-4), 195-220. https://doi. org/10.1016/0031-0182(95)00086-0.

Bourke, M.C., Ewing, R.C., Finnegan, D., McGowan, H.A. 2009. Sand dune movement in the Victoria Valley, Antarctica. Geomorphology 109, 14-160. https://doi.org/10.1016/j. geomorph/2009.02.028.

Brookfield, M.E. 2011. Aeolian processes and features in cool climates. In: Martini,I.P.,French, H.M., Pérez Alberti, A. (Eds.), Ice-marginal and periglacial processes and sediments. Geological Society of London, Special Publication, 354, pp. 241-258. https://doi.org/10.1144/SP354.16.

Burton-Johnson, A., Black, M., Fretwell, P.T., Kaluza-Gilbert, J. 2016. An automated methodology for differentiating rock from snow, clouds and sea in Antarctica from Landsat 8 imagery: a new rock outcrop map and area estimation for the entire Antarctic continent. Cryosphere 10 (4), 1665-1677. https://doi.org/10.5194/tc-101665-2016.

Carrivick, J.L., Davies, B.J., Glasser, N.F., Nývlt, D., Hambrey, M.J. 2012. Late-Holocene changes in character and behaviour of land-terminating glaciers on James Ross Island, Antarctica. Journal of Glaciology 58 (212), 1176-1190. https://doi.org/10.3189/2012JoG11J148.

Crame, J.A., Pirrie, D., Riding, J.B., Thomson, M.R.A. 1991. Campanian-Maastrichtian (Cretaceous) stratigraphy of the James Ross Island area, Antarctica. Journal of the Geological Society, London 148, 1125-1140. https://doi.org/10.1144/gsjgs.148.6.1125.

Davies, B.J., Hambrey, M.J., Smellie, J.L., Carrivick, J.L., Glasser, N.F. 2012. Antarctic Peninsula Ice Sheet evolution during the Cenozoic Era. Quaternary Science Reviews 31, 30-66. https:// doi.org/10.1016/j.quascirev.2011.10.012.

Davies, B.J., Glasser, N.F., Carrivick, J.L., Hambrey, M.J., Smellie, J.L., Nývlt, D. 2013. Landscape evolution and ice-sheet behaviour in a semi-arid polar environment: James Ross Island, NE Antarctic Peninsula. In: Hambrey, M.J., Barker, P.F., Barrett, P.J., Bownam, V., Davies, B., Smellie, J.L., Tranter, M. (Eds.), Antarctic Palaeoenvironments and EarthSurface Processes. Geological Society of London, Special Publication, 381, pp. 353-395. https://doi.org/10.1144/SP381.1.

Davies, B.J., Golledge, N.R., Glasser, N.F., Carrivick, J.L., Ligtenberg, S.R.M., Barrand, N.E., van den Broeke, M., Hambrey, M.J., Smellie, J.L. 2014. Modelled glacier response to centennial 
temperature and precipitation trends on the Antarctic Peninsula. Nature Climate Change 4 (11), 993-998. https://doi.org/10.1038/nclimate2369.

Del Valle, R.A., Elliot, D.H., Macdonald, D.I.M. 1992. Sedimentary basins on the east flank of the Antarctic Peninsula: proposed nomenclature. Antarctic Science 4, 477-478. https://doi. org/10.1017/S0954102092000695.

Engel, Z., Nývlt, D., Láska, K. 2012. Ice thickness, areal and volumetric changes of Davies Dome and Whisky Glacier (James Ross Island, Antarctic Peninsula) in 1979-2006. Journal of Glaciology 58 (211), 904-914. https://doi.org/10.3189/2012JoG11J156.

Engel, Z., Láska, K., Nývlt, D., Stachoň, Z. 2018. Surface mass balance of small glaciers on James Ross Island, north-eastern Antarctic Peninsula, during 2009-2015. Journal of Glaciology 64 (245), 349-361. https://doi.org/10.1017/jog.2018.17.

Evans, D.J.A., Ed. 2003. Glacial Landsystems. 532 pp., Arnold, London.

Eyles, N. 1983. Glacial geology: a landsystem approach. In: N. Eyles (Ed.), Glacial Geology: An Introduction for Engineers and Earth Scientists. Pergamon Press, Oxford, pp. 1-18. https:// doi.org/10.1016/B978-0-08-030263-8.50007-5.

Frauenfeld, O.W., Zhang, T., McCreight, J.L., 2007. Northern hemisphere freezing/thawing index variations over the twentieth century. International Journal of Climatology 27, 47-63. https:// doi.org/10.1002/joc 1372 .

French, H.M. 2017. The Periglacial Environment. $4^{\text {th }}$ Edition. Wiley-Blackwell, Oxford, 515 pp.

Gillies, J.A., Nickling, W.G., Tilson, M. 2013. Frequency, magnitude, and characteristics of aeolian sediment transport: McMurdo Dry Valleys, Antarctica. Journal of Geophysical ResearchEarth Surface 118 (2), 461-479. https://doi.org/10.1002/jgrf.20007.

Glasser, N.F., Davies, B.J., Carrivick, J.L., Rodés, A., Hambrey, M.J., Smellie, J.L., Domack, E. 2014. Ice-stream initiation, duration and thinning on James Ross Island, northern Antarctic Peninsula. Quaternary Science Reviews 86, 78-88. https://doi.org/10.1016/j. quascirev.2013.11.012.

Hedding, D.W., Nel, W., Anderson, R.L. 2015. Aeolian processes and landforms in the subAntarctic: preliminary observations from Marion Island. Polar Research 34 (1), 26365. https://dx.doi.org/10.3402/polar.v34.26365.

Hjort,C., Ingólfsson, Ó., Möller, P.,Lirio, J.M. 1997. Holocene glacial history and sea-level changes on James Ross Island, Antarctic Peninsula. Journal of Quaternary Science 12, 259-273. https://doi.org/10.1002/(SICI)1099-1417(199707/08)12:4<259::AID-JQS307>3.3.CO;2-Y.

Hrbáček, F., Láska, K., Engel, Z. 2016. Effect of Snow Cover on the Active-Layer Thermal Regime - A Case Study from James Ross Island, Antarctic Peninsula. Permafrost and Periglacial Processes 27, 307-315. https://doi.org/10.1002/ppp.1871.

Hrbáček, F., Nývlt, D., Láska, K. 2017. Active layer thermal dynamics at two lithologically different sites on James Ross Island, Eastern Antarctic Peninsula. Catena, 149, 592-602. https://doi.org/10.1016/j.catena.2016.06.020.

Hrbáček, F., Vieira, G., Oliva, M., Balks, M., Guglielmin, M., de Pablo, M.A., Molina, A., Ramos, M., Goyanes, G., Meiklejohn, I., Abramov, A., Demidov, N., Fedorov-Davydov, D., Lupachev, A., Rivkina, E., Láska, K., Kňažková, M., Nývlt, D., Raffi, R., Strelin, J., Sone, T., Fukui, K., Dolgikh, A., Zazovskaya, E., Mergelov, N., Osokin, N., Miamin, V., 2019. Active layer monitoring in Antarctica: an overview of results from 2006 to 2015. Polar Geography, in press. https://doi.org/10.1080/1088937X.2017.1420105.

Johnson, J.S., Bentley, M.J., Roberts, S.J., Binnie, S.A., Freeman, S.P.H.T. 2011. Holocene deglacial history of the northeast Antarctic Peninsula - A review and new chronological constraints. Quaternary Science Reviews 30,3791-3802.https://doi.org/10.1016/j.quascirev.2011.10.011.

Kavan, J., Dagsson-Waldhauserova, P., Renard, J.B., Láska, K., Ambrožová, K. 2018. Aerosol concentrations in relationship to local atmospheric conditions on James Ross Island, 
Antarctica. Frontiers in Earth Science-Atmospheric Science 6, 207. https://doi.org/10.3389/ feart.2018.00207.

Košler, J., Magna, T., Mlčoch, B., Mixa, P., Nývlt, D., Holub, F.V. 2009. Combined Sr, Nd, Pb and $\mathrm{Li}$ isotope geochemistry of alkaline lavas from northern James Ross Island (Antarctic Peninsula) and implications for back-arc magma formation. Chemical Geology 258, $207-$ 218. https://doi.org/10.1016/j.chemgeo.2008.10.006.

Koster, E.A., Dijkmans, J.W.A. 1988. Niveo-aeolian deposits and denivation forms, with special reference to the Great Kobuk sand dunes, northwestern Alaska. Earth Surface Processes and Landforms 13 (2), 153-170. https://doi.org/10.1002/esp.3290130206.

Kovanan, D., Slaymaker, O. 2015. The paraglacial geomorphology of the Fraser Lowland, southwest British Columbia and northwest Washington. Geomorphology 232, 78-93. https:// doi.org/10.1016/j.geomorph.2014.12.021.

Lancaster, N. 2002. Flux of eolian sediment in the McMurdo Dry Valleys, Antarctica: a preliminary assessment. Arctic, Antarctic, and Alpine Research 34 (3), 318-323. https://doi.org/10.1080/1 5230430.2002 .12003500 .

Lancaster, N. 2004. Relations between aerodynamic and surface roughness in a hyper-arid cold desert: McMurdo Dry Valleys, Antarctica. Earth Surface Processes and Landforms 29 (7), 853-867. https://doi.org/10.1002/esp.1073.

López-Martínez, J., Serrano, E., Schmid, T., Mink, S., Linés, C. 2012. Periglacial processes and landforms in the South Shetland Islands (northern Antarctic Peninsula region). Geomorphology 155, 62-79. https://doi.org/10.1016/j.geomorph.2011.12.018.

Marchant, D.R., Lewis, A.R., Phillips, W.M., Moore, E.J., Souchez, R.A., Denton, G.H., Sugden, D.E., Potter, N., Landis, G.P. 2002. Formation of patterned ground and sublimation till over Miocene glacier ice in Beacon Valley, southern Victoria Land, Antarctica. Geological Society of America Bulletin 114 (6), 718-730. https://doi.org/10.1130/0016-7606(2002)114<0718:FO PGAS $>3.3 . C O ; 2$.

Matsuoka, N., Moriwaki, K., Hirakawa, K. 1996. Field experiments on physical weathering and wind erosion in an Antarctic cold desert. Earth Surface Processes and Landforms 21, 687-699. https://doi.org/10.1002/(SICI)1096-9837(199608)21:8<687::AID-ESP614>3.3.CO;2-A.

McGowan, H.A., Neil, D.T., Speirs, J.C. 2014 . A reinterpretation of geomorphological evidence for Glacial Lake Victoria, McMurdo Dry Valleys, Antarctica. Geomorphology 208, 200-206. https://doi.org/10.1016/j.geomorph.2013.12.005.

McKenna Neuman, C. 1993. A review of aeolian transport processes in cold environments. Progress in Physical Geography: Earth and Environment 17 (2), 137-155. https://doi. org/10.1177/030913339301700203.

McKenna Neuman, C. 2004. Effects of temperature and humidity upon the transport of sedimentary particles by wind. Sedimentology 51, 1-17. https://doi.org/10.1046/j.13653091.2003.00604.x.

Mlčoch, B., Nývlt, D., Mixa, P., (Eds.) 2018. Geological map of James Ross Island - Northern part 1: 25,000. Czech Geological Survey, Praha.

Nelson, P.H.H. 1975. The James Ross Island Volcanic Group of North-East Graham Land. British Antarctic Survey Scientific Report 54, 62 pp.

Nývlt, D., Braucher, R., Engel, Z., Mlčoch, B., ASTER Team 2014. Timing of the Northern Prince Gustav Ice Stream retreat and the deglaciation of northern James Ross Island, Antarctic Peninsula during the last glacial-interglacial transition. Quaternary Research 82, 441-449. https://doi.org/10.1016/j.yqres.2014.05.003.

Nývlt, D., Nývltová Fišáková, M., Barták, M., Stachoň, Z., Pavel, V., Mlčoch, B., Láska, K. 2016. Death age, seasonality, taphonomy and colonization of seal carcasses from Ulu Peninsula, 
James Ross Island, Antarctic Peninsula. Antarctic Science 28, 3-16. https://doi.org/10.1017/ S095410201500036X.

Ó Cofaigh, C., Davies, B.J., Livingstone, S.J., Smith, J.A., Johnson, J.S., Hocking, E.P., Hodgson, D.A., Anderson, J.B., Bentley, M.J., Canals, M., Domack, E., Dowdeswell, J.A., Evans, J., Glasser, N.F.,Hillenbrand,C.D.,Larter,R.D., Roberts, S.J., Simms, A.R. 2014. Reconstruction of ice-sheet changes in the Antarctic Peninsula since the Last Glacial Maximum. Quaternary Science Reviews 100, 87-110. https://doi.org/10.1016/j.quascirev.2014.06.023.

Oliva, M., Ruiz-Fernández, J. 2015. Coupling patterns between para-glacial and permafrost degradation responses in Antarctica. Earth Surface Processes and Landforms 40 (9), 1227 1238. https://doi.org/10.1002/esp.3716.

Oliva, M., Hrbáček, F., Ruiz-Fernández, J., de Pablo, M.A., Vieira, G., Ramos, M., Antoniades. D. 2017. Active layer dynamics in three topographically distinct lake catchments in Byers Peninsula (Livingston Island, Antarctica). Catena 149 (2), 548-559. https://doi. org/10.1016.j.catena.2016.07.011.

Olivero, E., Scasso, R.A., Rinaldi, C.A. 1986. Revision of the Marambio Group, James Ross Island, Antarctica. Instituto Antártico Argentino, Contribución 331, 28 pp.

Šabacká, M., Priscu, J.C., Basagic, H.J., Fountain, A.G., Wall, D.H., Virginia R.A., Greenwood, M.C. 2012. Aeolian flux of biotic and abiotic material in Taylor Valley, Antarctica. Geomorphology 155-156, 102-111. https://doi.org/10.1016/j.geomorph/2011.12.009.

Seehaus, T., Cook, A.J., Silva, A.B., Braun, M. 2018. Changes in glacier dynamics in the northern Antarctic Peninsula since 1985. Cryosphere 12 (2), 577-594. https://doi.org/10.5194/tc12577-2018.

Seppälä, M. 2004. Wind as a geomorphic agent. Cambridge University Press, Cambridge, 368 pp.

Smellie, J.L., Johnson, J.S., Mcintosh, W.C., Esser, R., Gudmundsson, M.T., Hambrey, M.J., Van Wyk De Vries, B. 2008. Six million years of glacial history recorded in volcanic lithofacies of the James Ross Island Volcanic Group, Antarctic Peninsula. Palaeogeography, Palaeoclimatology, Palaeoecology 260, 122-148. https://doi.org/10.1016/j.palaeo/2007.08.011.

Smellie, J.L., Johnson, J.S., Nelson, A.E. 2013. Geological map of James Ross Island. I. James Ross Island Volcanic Group (1:125 000 Scale). BAS GEOMAP 2 Series, Sheet 5, British Antarctic Survey, Cambridge.

Smith, M.W., Riseborough, D.W. 1996. Permafrost Monitoring and Detection of Climate Change. Permafrost and Periglacial Processes 7, 301-309. https://doi.org/10.1002/(SICI)10991530(199610)7:4<301::AID-PPP231>3.0.CO;2R.

Speirs, J.C., McGowan, H.A., Neil, D.T. 2008. Meteorological controls on sand transport and dune morphology in a polar-desert: Victoria Valley, Antarctica. Earth Surface Processes and Landforms 33 (12), 1875-1891. https://doi.org/10.1002/esp.1739.

Thomas, D.S.G. 1997. Arid Zone Geomorphology. $2^{\text {nd }}$ Edition. John Wiley \& Sons, 624 pp.

Tsoar, H. 2001. Types of Aeolian Sand Dunes and Their Formation. In: N.J. Balmforth, A. Provenzale (Eds.) Geomorphological Fluid Mechanics. Lecture Notes in Physics, vol. 582. Springer, Berlin, Heidelberg.

Van Lipzig, N.P.M., King, J.C., Lachlan-Cope, T.A., van der Broeke, M.R. 2004. Precipitation, sublimation and snow drift in the Antarctic Peninsula region from a regional atmospheric model. Journal of Geophysical Research-Atmosphere 109, D24106. https://doi. org/10.1029/2004JD004701.

Wiggs, G., Baird, A., Atherton, R. 2004. The dynamic effects of moisture on the entrainment and transport of sand by wind. Geomorphology 59, 13-30. https://doi.org/10.1016/j. geomorph.2003.09.002.

Zhang, T. 2005. Influence of the seasonal snow cover on the ground thermal regime: an overview. Reviews of Geophysics 43 (4). https://doi.org/10.1029/2004RG000157. 
